\title{
Sistem Pakar Mendiagnosa Penyakit Keputihan Pada Wanita Dengan Metode Teorema Bayes
}

\author{
Christina Simanjuntak ${ }^{1 *}$, Fristi Riandari ${ }^{2}$ \\ ${ }^{1,2}$ STMIK Pelita Nusantara \\ Jl. Iskandar Muda No. 1 Medan 20154 Indonesia \\ Corresponding author's e-mail: chrissimanjuntak08@gmail.com
}

\begin{abstract}
Abstrak - Keputihan merupakan keluarnya cairan selain darah dari liang vagina, apabila keputihan tidak normal dibiarkan saja tanpa diobati, akibatnyainfeksi bisa menjalar, masuk ke dalam rahim, saluran telur, dan bisa sampaimenginfeksi ovarium.Penerapan sistem pakar pada bidang kesehatan akan sangat membantu dalam kelangsungan hidup seseorang. Sistem pakar dapat membantu mendiagnosis suatu jenis penyakit berdasarkan gejala yang dirasakan sendiri dengan cepat dan tepat. Sistem pakar yang dirancang sebagai alat bantu untuk mendiagnosa jenis penyakit keputihan khususnya pada wanita yang mengalami keputihan namun sering kali mereka merasa mampu mengenali sendiri bahwa sedang menderita keputihan tanpa merasa perlu memeriksakan diri ke dokter untuk memperoleh pemeriksaan secara lebih detail, dan hanya diobati sendiri dengan obat-obat keputihan yang dijual bebas.Sistem pakar ini akan menampilkan pilihan gejala yang dapat dipilih oleh user, selanjutnya akan mendapatkan hasil akhir dengan metode teorema bayes dengan memberikan hasil diagnosis berupa nilai probabilitas kemunculan setiap jenis penyakit dan solusi. Aplikasi sistem pakar dibangun berbasis web menggunakan HTML, PHP, CSS menggunakan database mysql.
\end{abstract}

Kata kunci: keputihan wanita, sistem pakar, diagnosa penyakit, Teorema Bayes

Abstract - Leucorrhoea is a discharge other than blood from the vaginal canal, if abnormal vaginal discharge is left untreated, as a result the infection can spread, enter the uterus, fallopian tubes, and can infect the ovaries. The application of an expert system in the health sector will greatly assist in survival someone. Expert systems can help diagnose a type of disease based on their own symptoms quickly and precisely. An expert system that is designed as a tool to diagnose the type of leucorrhoea, especially in women who experience vaginal discharge, but often they feel able to recognize themselves that they are suffering from vaginal discharge without feeling the need to go to a doctor for a more detailed examination, and only treat themselves with medication. Free-sale vaginal discharge medication. This expert system will display a selection of symptoms that can be selected by the user, then get the final result with the Bayes theorem method by providing a diagnosis result in the form of a probability value for the emergence of each type of disease and solution. Expert system applications are built on a web basis using HTML, PHP, CSS using the mysql database. Keywords: female vaginal discharge, expert system, disease diagnosis, Bayes Theorem

\section{Pendahuluan}

Pada masa ini, yang mengalami masa pubertas ditandai dengan menstruasi. Sebelum atau sesudah menstruasi remaja putri dapat mengalami keputihan. Remaja putri harus memahami tentang keputihan agar mereka tahu bagaimana cara menjaga kebersihan organ reproduksinya. Keputihan merupakan keluarnya cairan selain darah dari liang vagina, apabila keputihan tidak normal dibiarkan saja tanpa diobati, akibatnya infeksi bisa menjalar, masuk ke dalam rahim, saluran telur, dan bisa sampai menginfeksi ovarium. Dampak keputihan pada remaja dapat berpengaruh terhadap kesuburan bahkan kematian. Gangguan kesuburan banyak terjadi akibat karena sudah menjalar sampai ke organ reproduksi yang lebih atas, yakni rahim dan saluran telur. Pada kasus ini, tindakan tersebut cukup beresiko, karena apabila kurang tepat dalam pengenalan penyakitnya dapat menyebabkan kurang tepat pula obat yang dipilih, sehingga selain efektivitas terapi tidak tercapai juga akan beresiko pada munculnya resistensi sehingga jamur semakin kebal dengan obat. Sistem pakar dapat membantu mendiagnosis suatu jenis penyakit berdasarkan gejala yang dirasakan sendiri dengan cepat dan tepat. Sistem pakar menirukan perilaku seorang pakar dalam menangani suatu persoalan. Bila dokter cukup sibuk dan pelaksana diagnosa digantikan oleh sebuah sistem pakar, maka sistem pakar diharapkan dapat membantu memahami dan menganalisa keadaan pasien dan menemukan penyakit yang diderita pasien itu. Sistem pakar diharapkan juga untuk menghasilkan dugaan atau hasil diagnosa yang sama dengan diagnosa yang dilakukan oleh seorang ahli [1].

Teorema Bayes yang merupakan salah satu metode yang digunakan untuk menghitung ketidakpastian data menjadi data yang pasti dengan membandingkan antara data "ya" atau "tidak". Metode digunakan dalam menyelesaikan permasalahan yang berkaitan denganpengambilan keputusan. Dimana pendekatan secara statistik dalam mengitung trede-off diantara keputusan yang berbeda-beda, dengan menggunakan probabilitas 
dan costs yang menyertai suatu pengambilan keputusan [2]. Probabilitas bayes merupakan salah satu cara untuk mengatasi ketidakpastian data dengan cara menggunakan formula bayes [3]. Maka metode ini dapat dipakai untuk mendukung pengambilan keputusan dalam mendiagnosa penyakit keputihan pada wanita.Penelitian Sistem Pakar Diagnosa Penyakit Gigi Menggunakan Metode Naive Bayes menjelaskan, sistem pakar memperkenalkan implementasi diagnosa penyakit gigi. Sipenderita dapat mengobati sakit gigi dengan arahan dari kommputer (pakar). Pakar sebagai sumber data basis pengetahuan diwakilkan komputer mendiagnosa penyakit. Menurut pakar gigi ada 7 jenis penyakit dengan 37 gejala (dikodekan sesuai kriteria). Dalam Naïve Bayes, pengklasifikasian menggunakan metode probabilitas dan statistik. Perhitungan Naïve Bayes berdasarkan data penyakit dan data gejala dengan variable Data, Hipotesa dan Probabilitas. Dari data yang diuji sesuai kasus diketahui probabilitas Penyakit Halitosis adalah yang tertinggi dari penyakit lain yaitu 0.29646 atau $29.64 \%$ [4].

Penelitian Rancang Bangun Sistem Pakar Diagnosis Penyakit Mata Dengan Metode Teorema Bayes menjelaskan Teorema Bayes digunakan untuk menghitung probabilitas terjadinya suatu peristiwa berdasarkan pengaruh yang didapat dari hasil observasi. Metode ini disamping memanfaatkan data sampel yang diperoleh dari populasi menghitung suatu distribusi awal yang disebut distribusi prior [5]. Penelitian Pemanfatan Teorema Bayes Dalam Penentuan Penyakit THT dijelaskan Dengan memberikan knowledge-base / basis pengetahuan yang dimiliki oleh seorang pakar (dokter) dapat disimpan pada sebuah sistem komputer. Basis pengetahuan tersebut diharapkan dapat mendiagnosa penyakit yang diderita seorang pasien dengan mengidentifikasi gejala yang dirasakan sebagai dasar masukan atau inputannya, maka sistem tersebut dapat bekerja dengan baik untuk mendiagnosa penyakit yang diderita seorang pasien dengan mengidentifikasi gejala yang dirasakan [6]

\section{Tinjauan Pustaka}

\subsection{Sistem Pakar (Expert System)}

Sistem pakar atau Expert system bisa disebut juga dengan Knowledge Based System yaitu suatu aplikasi komputer yang ditujukan untuk pengambilan keputusam atau pemecahan persoalan dalam bidang yang spesifik [7]. Sistem ini bekerja dengan mengunakan pengetahuan dan metode analisis yang telah didefinisikan terlebih dahulu oleh pakar yang sesuai dengan bidang ahlinya. Sistem ini disebut sistem pakar karena fungsi dan perannya sama seperti seorang ahli yang memiliki pengetahuan, pengalaman, dalam memecahkan sesuatu persoalan [8]. Sistem biasanya berfungsi sebagai kunci penting yang akan membantu suatu sistem pendukung keputusan atau sistem pendukung eksekutif. Tujuan utama sistem pakar adalah untuk memindahkan secara efektif ilmu pengetahuan kepada mereka yang bukan pakar. Sistem pakar mempunyai 3 bagian utama, yaitu user interface, inference engine, dan knowledge base [9].

2.2 Teorema Bayes

Dalam teori probabilitas dan statistika, Teorema Bayes adalah sebuah teorema dengan dua penafsiran berbeda. Dalam penafsiran Bayes, teorema ini menyatakan seberapa jauh derajat kepercayaan subjektif harus berubah secara rasional ketika ada petunjuk baru [10]. Dalam penafsiran frekuentis teorema ini menjelaskan representasi invers probabilitas dua kejadian. Teorema ini merupakan dasar dari statistika Bayes dan memiliki penerapan dalam sains, rekayasa, ilmu ekonomi terutama ilmu ekonomi mikro, teori permainan, kedokteran dan hukum. Penerapan teorema Bayes untuk memperbarui kepercayaan dinamakan inferens Bayes [11]. Probabilitas bayes adalah salah satu cara untuk mengatasi ketidakpastian data [12] [13].

\section{Metode Penelitian}

Langkah-langkah penelitian, dijelaskan sebagai berikut :

1. Identifikasi masalah

Pada tahap awal penelitian dimulai dengan menentukan kebutuhan dan data penelitian daintaranya mengenai teori dan metode teorema bayes, jenis penyakit dengan gejala keputihan pada wanita, setelah itu data dikumpulkan dan menyiapkan alat dan bahan penelitian. Studi Literatur dilakukan dengan mempelajari dan memahami teori-teori yang digunakan, yaitu mencari gejala-gejala atau faktor-faktor yang menjadi gejala pada penyakit keputihan, teori metode teorema bayes, perhitungan nilai probabilitas,

2. Observasi

Observasi dilakukan dengan mengadakan wawancara langsung kepada pakar terhadap permasalahan yang diambil untuk mendapatkan data yang akurat mengenai penyakit keputihan, serta mempelajari metode Teorema Bayes. Dari hasil studi literatur dan observasi ditemukan data penelitian yaitu jenis penyakit keputihan beserta karakteristik atau gejala penyakit keputihan, teori Teorema Bayes. 


\section{Analisis}

Pada tahap analisis ini mendeskripsikan perangkat lunak dan mendeskripsikan kebutuhan dan analisis sistem yang dibangun, pada tahap perancangan yaitu perancangan basis data, perancangan masukan, perancangan keluaran dan perancangan antarmuka perangkat lunak.

4. Metode Teorema Bayes

Pada penelitian ini menggunakan metode teorema bayes untuk menghitung kaidah probabilitas terjadinya suatu peristiwa berdasarkan pengaruh didapat dari diservasi. Teorema ini menerangkan hubungan antara probabilitas terjadinya suatu peristiwa (misal A) dengan syarat peristiwa lain (misal X) telah terjadi sehingga akan menghasilkan sebuah nilai kepastian apakah pasien tersebut menderita suatu penyakit keputihan.

5. Implementasi dan Pengujian

Pada tahap kode dilakukan penerjemahan desain perangkat lunak kedalam bahasa pemrograman, setelah menerjemahkan desain perangkat lunak menggunakan bahasa pemrograman, maka dilakukan pengujian sistem terhadap hasil analisis.

6. Kesimpulan

Setelah hasil dari penelitian atau objek sudah didapatkan melalui proses testing selanjutnya dianalisa untuk mendapatkan kesimpulan apakah penerapan metode teorema bayes dapat mendiagnosa penyakit keputihan pada wanita dengan tingkat akurasi yang tinggi, dan sistem pakar mendiagnosa penyakit keputihan dengan metode teorema bayesmemberikan solusi dalam mengatasi penyakit keputihan serta solusi untuk menangani penyakit keputihan yang diderita secara cepat. Setelah proses dan tahapan sudah dilewati kemudian akan didokumentasikan menjadi sebuah hasil penelitian.

\section{Hasil dan Pembahasan}

Data yang akan dibutuhkan dalam pembuatan sistem ini adalah sebagai berikut:

a. Data Pasien

Data Pasien ini dibutuhkan untuk mengetahui informasi pasien yang akan melakukan diagnosa penyakit keputihan.

b. Data gejala

Data gejala ini dibutuhkan untuk pengelompokan jenis gejala berdasarkan penyakit yang dialami oleh pasien.

c. Data solusi

Data solusiini berisikan solusi berasal dari pakar yang bisa dilakukan sebagai langkah awal serta saran dalam terhadap penyakit keputihan yang dialami pasien.

d. Data nilai probabilitas Teorema Bayes

Data nilai probabilitas Teorema Bayes ini berisikan data nilai probabilitas densitas masing-masing hipotesis yang diperoleh dari nilai probabilitas densitas evidencenya.

Metode yang digunakan adalah metode Teorema Bayes. Proses perhitungan dengan Teorema Bayes dimulai dari menentukan tingkat kemungkinan (Probabilitas) penyebab terjadinya penyakit keputihan pada wanita dengan memberikan rentang nilai sebagai presentase keyakinan dalam menentukan sebuah keputusan kemudian dikali dengan sebuah hipotesa terhadap sebuah keputusan setelah hasil bagi antara probabilitas dan hipotesa diperoleh maka langkah selanjutnya adalah melakukan pembagian dengan hasil kali keseluruhan dari probabilitas dan hasil hipotesa (kesimpulan sementara). 


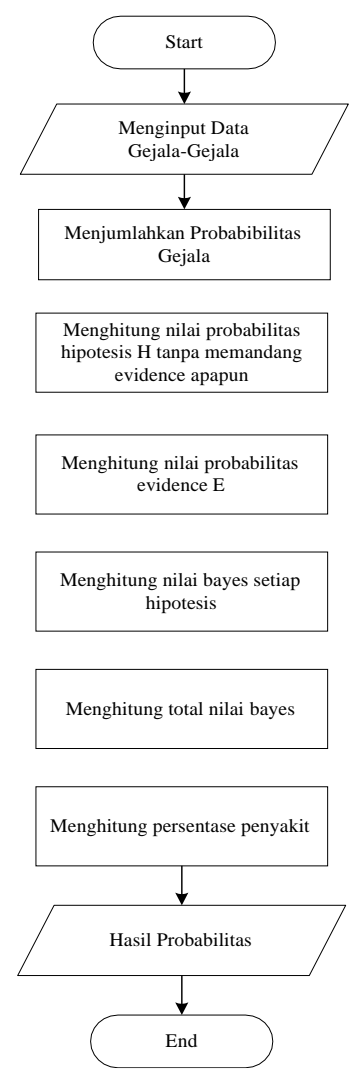

Gambar 1. Flowchart Teorema Bayes

Basis pengetahuan yang digunakan di dalam sistem pakar ini terdiri dari gejala-gejala yang diderita oleh pasien serta nama penyakit. Jenis penyakit keputihan yang terjadi wanita P01= Keputihan Normal, P02 = Keputihan Trichomonas, P03 $=$ Keputihan Candida, P04 $=$ Keputihan Gardnerella, P05 $=$ Keputihan Gonococcus, P06 = Keputihan Gonore, P07 = Keputihan Vaginosis.

Contoh kasus: seorang pasien ingin melakukan diagnosa penyakit keputihan dengan menjawab pertanyaan sesuai dengan gejala, Setelah hasil jawaban dari pertanyaan yang diajukan, maka dilakukan perhitungan menggunakan Teorema Bayes untuk tiap gejala. Mendefinisikan terlebih dahulu nilai probabilitas dari tiap evidence untuk tiap hipotesis berdasarkan data sampel yang ada menggunakan rumus probabilitas bayes. Untuk penyakit keputihan normal P01 Keputihan Normal. G5 $=0.4=\mathrm{P}(\mathrm{E} \mid \mathrm{H} 1) \mathrm{G} 6=0.5=$ $\mathrm{P}(\mathrm{E} \mid \mathrm{H} 2) \mathrm{G} 7 \quad=0.4=\mathrm{P}(\mathrm{E} \mid \mathrm{H} 3)$. Setelah mendapatkan nilai $\mathrm{P}(\mathrm{Hi})$ probabilitas hipotesis $\mathrm{H}$ tanpa memandang evidence apa pun, maka langkah selanjutnya menghitung nilai probabilitas evidence $\mathrm{E}:=\mathrm{P}(\mathrm{H} 1)+\mathrm{P}(\mathrm{H} 2)+$ $\mathrm{P}(\mathrm{H} 3)=0.25+0.25+0.33=0.833$. Langkah terakhir adalah menghitung persentase dari total nilai Bayes : Berdasarkan gejala yang dipilih nilai untuk penyakit keputihan normal adalah sebagai berikut. Persentase $=$ $0.833 * 100 \%=8.33 \%$

Probabilitas (P2) Keputihan Trichomonas

$=\mathrm{P}(\mathrm{H} 1)+\mathrm{P}(\mathrm{H} 2)+\mathrm{P}(\mathrm{H} 3) * \mathrm{P}(\mathrm{H} 4)+\mathrm{P}(\mathrm{H} 5) * \mathrm{P}(\mathrm{E} \mid \mathrm{H} 5)+\mathrm{P}(\mathrm{H} 6) \mathrm{P}(\mathrm{H} 7)+\mathrm{P}(\mathrm{H} 8)+\mathrm{P}(\mathrm{H} 9)+\mathrm{P}(\mathrm{H} 10)=3.557$

Persentase $=3.557 * 100 \%=35.7 \%$ Probabilitas $(\mathrm{P} 3)$ Keputihan Candida G5 $=0.4=\mathrm{P}(\mathrm{E} \mid \mathrm{H} 1)$

$\mathrm{G} 6=0.5=\mathrm{P}(\mathrm{E} \mid \mathrm{H} 2) \mathrm{G} 10=0.6=\mathrm{P}(\mathrm{E} \mid \mathrm{H} 3) \mathrm{G} 11=0.4 \mathrm{P}(\mathrm{E} \mid \mathrm{H} 4) \mathrm{G} 12=0.8 \mathrm{P}(\mathrm{E} \mid \mathrm{H} 5) \mathrm{G} 14=0.5 \mathrm{P}(\mathrm{E} \mid \mathrm{H} 6)$

$\mathrm{G} 15=0.5 \mathrm{P}(\mathrm{E} \mid \mathrm{H} 7) \mathrm{G} 16=0.8 \mathrm{P}(\mathrm{E} \mid \mathrm{H} 8)$. Setelah mendapatkan seluruh nilai $\mathrm{P}(\mathrm{Hi} \mid \mathrm{E})$, maka langkah selanjutnya adalah menghitung total nilai Bayes: $=(0.25)+(0.25)+(0.16)+(0.16)+(0.25)+(0.33)+(0.38)$ $+(0.5)=2.301$. Persentase $=2.301 * 100 \%=20.31 \%$

Berdasarkan hasil perhitungan probalitas untuk setiap penyakit di dapatkan hasil di dalam tabel1.

Tabel 1. Hasil Perhitungan Probalitas

\begin{tabular}{|l|l|l||l|}
\hline Kode & Nama Penyakit & Bayes & Persen \\
\hline P01 & Keputihan Normal & 0.83 & $8.33 \%$ \\
\hline P02 & Keputihan Trichomonas & 3.56 & $35.6 \%$ \\
\hline P03 & Keputihan Candida & 2.3 & $23 \%$ \\
\hline
\end{tabular}




\begin{tabular}{|l|l|l||l|}
\hline P04 & Keputihan Gardnerella & 1.81 & $18.08 \%$ \\
\hline P05 & Keputihan Gonococus & 0.58 & $5.8 \%$ \\
\hline P06 & Keputihan Genore & 0.58 & $5.8 \%$ \\
\hline P07 & Keputihan Vaginosis & 0.33 & $3.3 \%$ \\
\hline
\end{tabular}

Dari hasil perhitungan di atas, maka dapat disimpulkan bahwa pasien tersebut menderita penyakit Keputihan Trichomonas dengan persentasi $35.6 \%$.

Implementasi terhadap sistem yang baru. Tahapan ini dilakukan setelah analisa dan perancangan selesai dilakukan dan selanjutnya akan diimplementasikan pada bahasa pemrograman yang akan digunakan. Setelah implementasi maka dilakukan pengujian sistem yang baru, dimana akan dilihat kekurangan-kekurangan pada aplikasi yang baru untuk pengembangan sistem selanjutnya.

Setelah melakukan tahap perancangan sistem dan implementasi perangkat lunak, maka tindakan selanjutnya yang dilakukan adalah penerapan hasil perangkat lunak tersebut.

a. Tampilan Halaman Utama

Halaman Utama pertama kali tampil pada saat aplikasi di jalankan,Gambar 2.

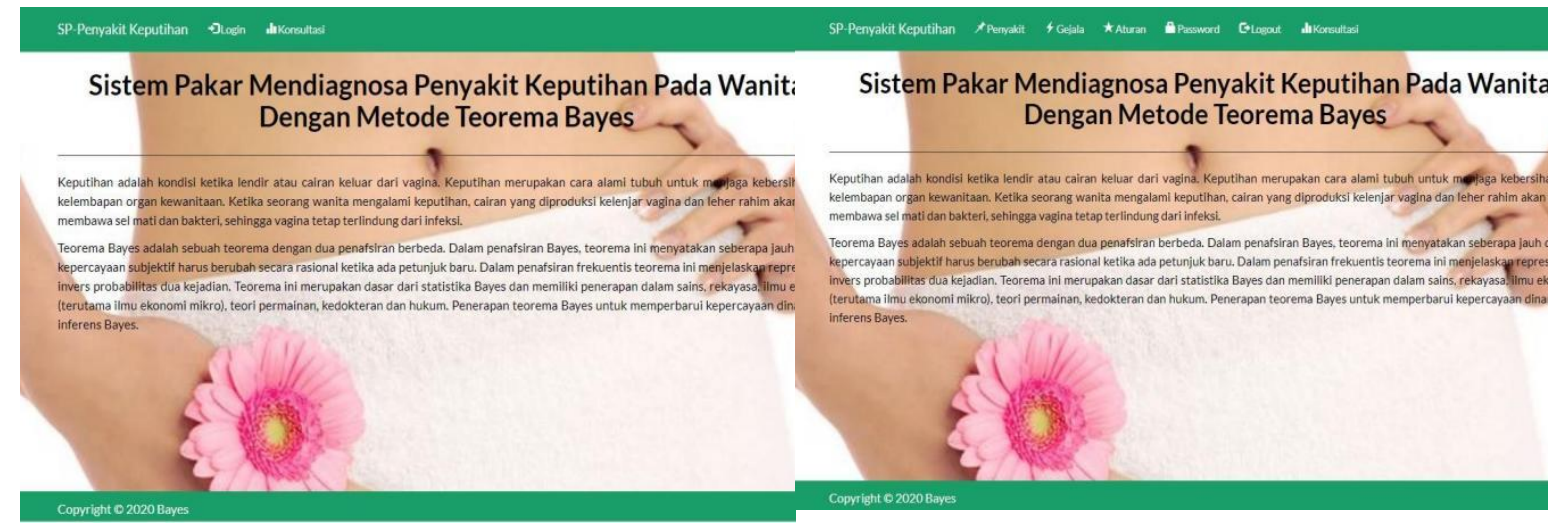

Gambar 2. Halaman Menu Utama

b. Tampilan Menu Penyakit

Pada tampilan menu penyakit berisikan data penyakit keputihan. Pada halaman ini user bisa menambah, mengubah dan menghapus jenis penyakit. Tampilan halaman dirancang agar mudah untuk digunakan oleh user.

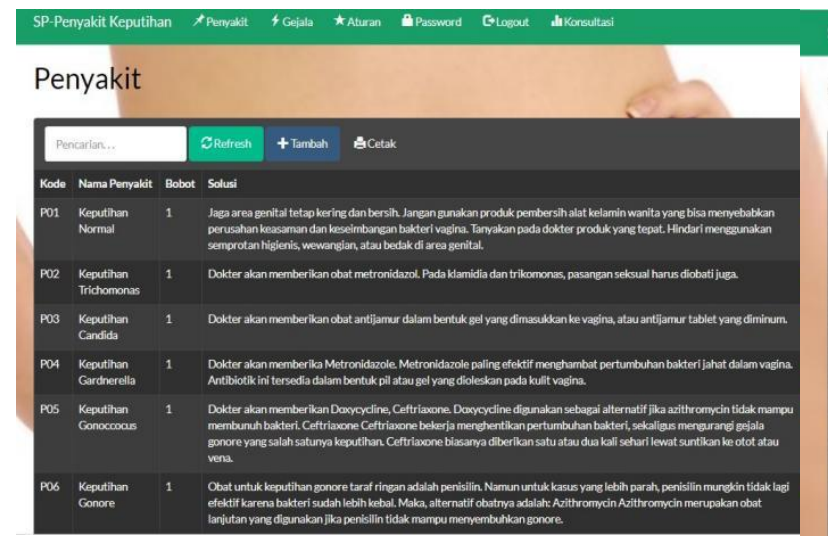

Gambar 3. Tampilan Halaman Penyakit

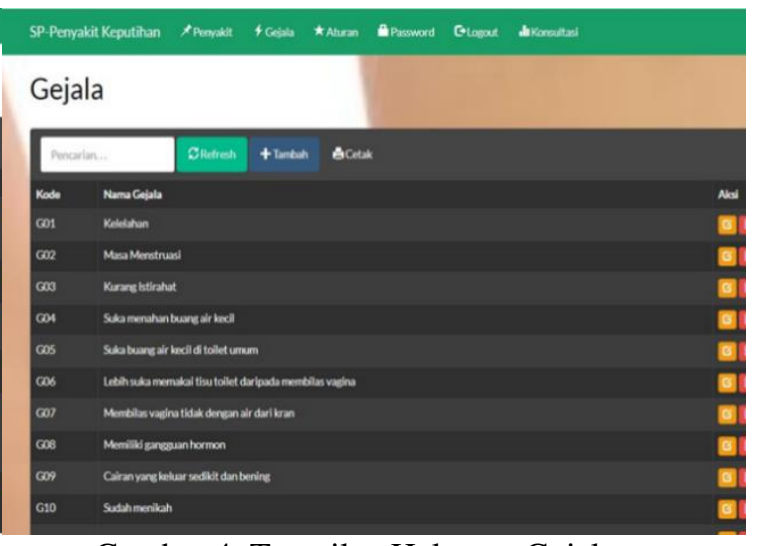

Gambar 4. Tampilan Halaman Gejala

3. Tampilan Halaman Hasil Konsultasi

Pada tampilan hasil konsultasi di peroleh setelah selesai menginputkan gejala yang dialami. Maka hasil diagnosa akan muncul dengan menampilakan nilai bayes dan persentase hasil. 

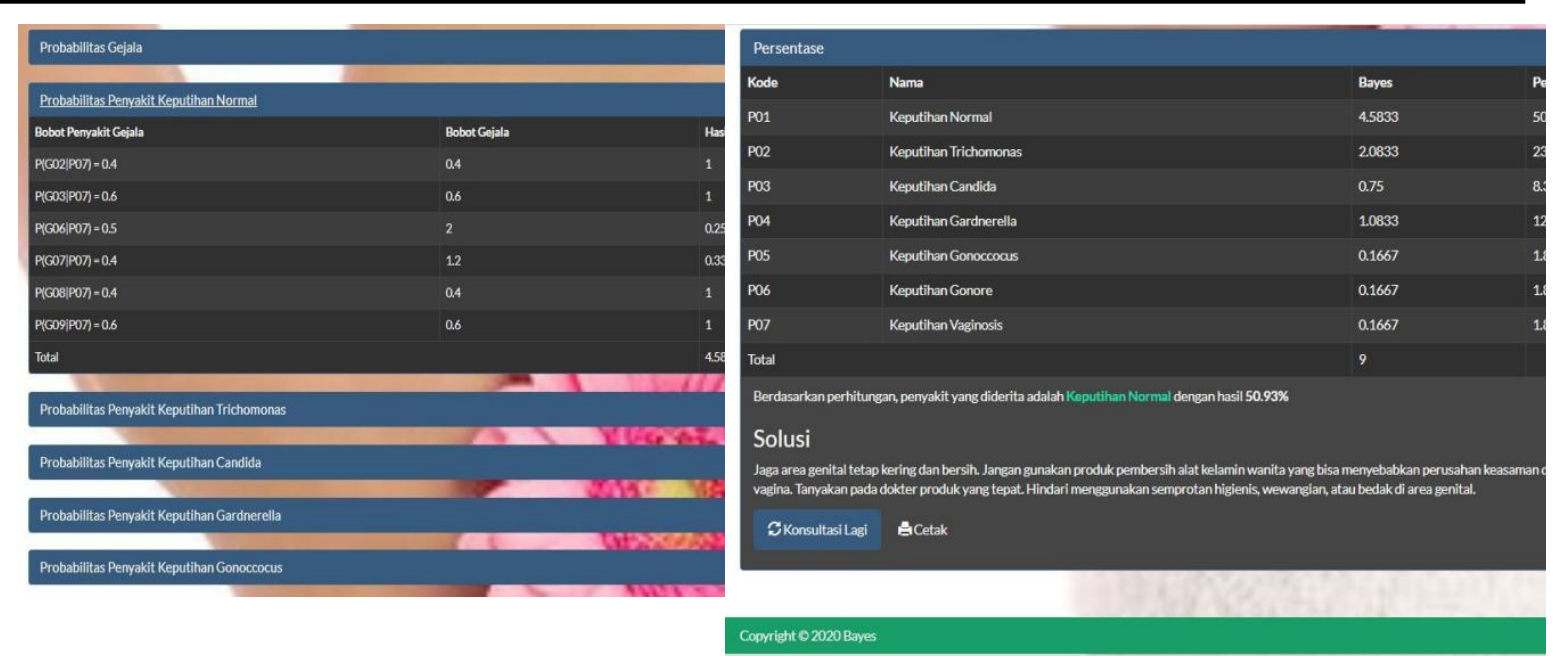

Gambar 5. Halaman Konsultasi

4. Tampilan Laporan Hasil Konsultasi

Laporan hasil konsultasi ini dapat di lihat setelah melakukan konsultasi lalu menekan tombol cetak yang ada dibawah. Berikut ini adalah laporan hasil konsultasi

\begin{tabular}{l}
\hline \hline 47. \\
47.18/2020 \\
$\qquad$\begin{tabular}{|l|l|l|l|}
\hline Kode & \multicolumn{1}{|c|}{ Nama } & \multicolumn{1}{l|}{ Bayes } & Persen \\
\hline P03 & Keputihan Candida & 0.5 & $7.14 \%$ \\
\hline P04 & Keputihan Gardnerella & 0.8333 & $11.9 \%$ \\
\hline P05 & Keputihan Gonoccocus & 0 & $0 \%$ \\
\hline P06 & Keputihan Gonore & 0 & $0 \%$ \\
\hline P07 & Keputihan Vaginosis & 0 & $0 \%$ \\
\hline Total & 7 & \\
\hline
\end{tabular}
\end{tabular}

Berdasarkan perhitungan, penyakit yang diderita adalah Keputihan Normal dengan hasil $\mathbf{6 9 . 0 5 \%}$

Gambar 6. Halaman Laporan Hasil Konsultasi

\section{Kesimpulan}

Kesimpulan dari penelitian :

1. Dengan menerapkan teorema bayes dalam mendiagnosa keputihan dapat menghasilkan perhitungan valid sehingga proses prediksi dapat dilakukan dengan cepat dan akurat.

2. Sistem ini tergolong user friendly terbukti hasil survey terhadap pengguna $85 \%$ menyatakan sangat mudah digunakan Sistem dibuat dengan tampilan yang user friendly sehingga mudah digunakan.

3. Sistem yang berbasis web dapat $\mathrm{d}$ akses oleh semua pasien karena sistem yang dijalankan pada aplikasi web.

\section{Daftar Pustaka}

[1] N. Sulardi and A. Witanti, "Sistem Pakar Untuk Diagnosis Penyakit Anemia Menggunakan Teorema Bayes," J. Tek. Inform., vol. 1, no. 1, pp. 19-24, 2020, doi: 10.20884/1.jutif.2020.1.1.12.

[2] R. T. Waruwu and A. Sindar, "SISTEM PAKAR MENENTUKAN JENIS GANGGUAN PERKEMBANGAN ANAK MENGGUNAKAN METODE CERTAINTY FACTOR,” vol. 2, no. 2, pp. 35-41, 2019.

[3] Y. Hendra, A. Parapat, and D. Juniansha, "Sistem Pakar Untuk Diagnosa Penyakit Kejiwaan Dengan Menggunakan Metode Teorema Bayes," J. Sist. Inf. dan Inform., vol. 3, no. 1, pp. 94-108, 2020, doi: 10.47080/simika.v3i1.855.

[4] Y. Yuliyana and A. S. R. M. Sinaga, "Sistem Pakar Diagnosa Penyakit Gigi Menggunakan Metode 
Naive Bayes," Fountain Informatics J., vol. 4, no. 1, p. 19, 2019, doi: 10.21111/fij.v4i1.3019.

[5] I. W. Priyana, "Rancang Bangun Sistem Pakar Diagnosis Penyakit Mata Dengan Metode Teorema Bayes," Edutic - Sci. J. Informatics Educ., vol. 2, no. 1, pp. 1-7, 2016, doi: 10.21107/edutic.v2i1.1551.

[6] S. Winiarti, "Pemanfatan Teorema Bayes Dalam Penentuan Penyakit Tht," Pemanfaat. Teorema Bayes Dalam Penentuan Penyakit THT, vol. 2, no. 2, pp. 209-219, 2008.

[7] A. Arifsyah and A. Sindar, "Sistem Pakar Diagnosa Penyakit Pohon Karet Dengan Metode Certainty Factor," J. Nas. Komputasi dan Teknol. Inf., vol. 2, no. 2, p. 175, 2019, doi: 10.32672/jnkti.v2i2.1568.

[8] H. Rohayani, "Sistem Pakar Pendeteksi Penyakit Kanker Ganas yang Menyerang Kaum Wanita," $J$. Process., vol. 5, no. 1, pp. 68-81, 2010.

[9] R. Saragih, "Sistem Pakar Mendiagnosa Penyakit Tumor Phyllodes Pada Wanita Menggunakan Metode Dempster Shafer," J. Inf. Syst. Res., vol. 1, no. 3, pp. 199-208, 2020, [Online]. Available: https://jurnal.kaputama.ac.id/index.php/JIK/article/view/280.

[10] A. P. Gusman, D. Maulida, and E. Rianti, "Sistem Pakar Diagnosa Penyakit Kista Ovarium Dengan Metode Forward Chaining," Komtekinfo, vol. 6, no. 1, pp. 8-18, 2019, doi: 10.29165/komtekinfo.v6i1.146.

[11] N. Y. S. Munti and F. A. Effindri, "Perancangan Aplikasi Sistem Pakar Diagnosa Penyakit Ginekologi Menggunakan Metode Forward Chaining Berbasis Web Mobile," J. Media Infotama, vol. 13, no. 2, pp. 67-72, 2017, doi: 10.37676/jmi.v13i2.454.

[12] Y. Nurfarianti, "Sistem Pakar Untuk Diagnosis Dismenore Menggunakan Metode Naïve Bayes," Progr. Stud. Inform. Univ. Tanjungpura, vol. 4, no. 1, pp. 1-6, 2016.

[13] A. S. R. Sinaga, M. Marbun, and A. S. Sitio, "Penerapan Teknologi Informasi Penentuan Prioritas Penerima Bantuan Langsung Tunai (BLT) desa Pagar Jati," Jurdimas (Jurnal Pengabdi. Kpd. Masyarakat) R., vol. 4, no. 1, pp. 65-70, 2021, doi: 10.33330/jurdimas.v4i1.681. 